\title{
OBITUARY
}

\section{ANDREW RUTHERFORD DAVIDSON}

(I890-I968)

Andrew Rutherford Davidson qualified as a Fellow in 1915 and, after war service in the artillery, took up his first official appointment as Assistant Actuary of the Standard Life in 1920. This was the start of an active and distinguished business career which led him by the successive steps of Agency Manager and Deputy Manager to the Managership of his office, a post which he held for nine years until ill health caused him to retire prematurely in 1951.

His services to the Faculty were equally distinguished. He was tutor, examiner, member of Council, Honorary Secretary from 1929 to 1932 and President from 1948 to 1950 . To each of these posts he brought his own characteristic blend of energy and ability. He was both an innovator and an enthusiast and it was by no means accidental that he seemed always to be in at the beginning of things. The Students' Society was formed in 1920 and he was its first Chairman. The Board of Examiners was set up in 1923 and he was its first Secretary. In 1931 the Faculty moved to its new premises, and he was its Honorary Secretary.

He was, however, more than simply an administrator. He also made a distinctive contribution to actuarial thought and was author, or joint author, of several notable actuarial papers on subjects as diverse as graduation methods and the application of punched card accounting machinery to life office work. Of these papers the most memorable is probably that entitled "On the Calculation of Rates of Mortality" which, jointly with A. R. Reid, he submitted to the Faculty on 31st January 1927, setting out the arguments for investigating mortality experience on the basis of consecutive human life, or 'generation mortality' as it came to be called. By an extraordinary coincidence a paper was submitted to the Institute of Actuaries on the same subject on the same evening by V. P. A. Derrick, but the general theory had been outlined by Davidson in the Transactions some time previously (T.F.A. vol. 10, p. 282) when reviewing the Report by the Government Actuary on the Mortality Experience of Government Life Annuitants, so he may fairly be given credit for the idea.

From 1932 onwards, Davidson's official connection with the Faculty diminished though he attended its meetings regularly and took part in discussions. In 1948, however, he was elected President and 
responded to the demands of the position with characteristic energy by delivering a wide-ranging and stimulating presidential address and later contributing to the Transactions an essay on probability-a subject in which he had always been keenly interested.

Soon after his term as President ended, he had a serious illness and his doctors advised him to retire, which he did reluctantly but cheerfully. About that time Council decided that a history of the Faculty should be prepared as part of the plans for the forthcoming centenary and invited Davidson to be the author. It was an inspired choice for he undertook the task enthusiastically. He searched, or caused others to search, all available records at the Faculty or elsewhere. By interview and letter he stirred the memories of his seniors and from every conceivable source, likely or unlikely, gathered together all that could be discovered about the Faculty's past. Then he wrote it down with elegance and wit and an amused affection for the Faculty and its people which recorded admiringly what had been done but permitted itself to smile at eccentricity or foible. The result was a book of which the Faculty can be proud and which has brought pleasure and interest to many outside the actuarial profession and everyone within it.

Davidson was a man of many interests. He was a keen and skilful angler and, so long as he was able, a day on a Highland loch or an evening on Threipmuir were outings to be looked forward to with boyish excitement. "If I were to be hanged tomorrow," he used to say, "I would like to go fishing tonight." Hewas also a keen and skilful chess player, asking only, as did Sarah Battle, for her whist, " a clear fire, a clean hearth and the rigour of the game"-though he would raise no objection if a good dinner preceded and a glass of good port accompanied the contest. Like a true son of Hawick, he was a devoted follower of rugby football with no pretensions to impartiality. Particularly in his retirement, he read widely and enjoyed discussing and arguing about what he had read.

All this tells something of what he did but gives an inadequate impression of what he was. In business and professional life, he was friendly and informal, with an irrepressible sense of humour. He was a hanging judge of pomposity or pretentiousness and his judgements were not pronounced sotto voce. Critics might say that his decisions were taken quickly and in his mental spectrum there were no greys-only black and white; he could be impatient, even contemptuous, of those whose minds worked more slowly, or who halted a little between two opinions; in the grip of an idea, he could not, or 
would not, relax until, all difficulties swept aside, it had been brought to accomplishment, and so he was an exciting but exacting man to work with. To such critics it can fairly be answered that those who worked most closely with him were among his closest friends.

In 1921 he married Miss Jean McKenzie, who had been a colleague in the office, and for him home with his wife and children, and latterly grandchildren, about him was the stable axis round which the changes of the years revolved. In recent years particularly, when his physical powers began to fail, he found great contentment at his own fireside with his family and his books about him, and many who went there, as they thought, to ' cheer him up ' came away themselves encouraged.

By his death, the Faculty loses a member who served it well as an actuary, willingly as an office bearer, and uniquely as a historian.

J.B.D. 